\title{
Metabolic Factors in Diffuse Idiopathic Skeletal Hyperostosis - A Review of Clinical Data
}

\author{
Sruti Pillai and Geoffrey Littlejohn*
}

\author{
Departments of Rheumatology and Medicine, Monash Health and Monash University, 246 Clayton Road, Clayton, \\ Victoria, 3168, Australia
}

\begin{abstract}
Objectives: We aimed to review the literature linking metabolic factors to Diffuse Idiopathic Skeletal Hyperostosis (DISH), in order to assess associations between growth factors and DISH.

Method: We identified studies in our personal database and PubMed using the following keywords in various combinations: "diffuse idiopathic skeletal hyperostosis", "ankylosing hyperostosis", "Forestier's disease", "diabetes", "insulin", "obesity", "metabolic", "growth factors", "adipokines", "glucose tolerance" and "chondrocytes".

Results: We were not able to do a systematic review due to variability in methodology of studies. We found positive associations between obesity (especially abdominal obesity), Type 2 diabetes mellitus, glucose intolerance, hyperinsulinemia and DISH.

Conclusion: Current research indicates that certain metabolic factors associate with DISH. More precise studies deriving from these findings on these and other newly identified bone-growth factors are needed.
\end{abstract}

Keywords: Bone, diabetes, DISH, diffuse idiopathic skeletal hyperostosis, growth factors, insulin, metabolic, obesity.

\section{INTRODUCTION}

Diffuse idiopathic skeletal hyperostosis (DISH) is a common skeletal disorder characterised by the presence of new bone formation. The new bone is particularly prominent in entheseal areas, where ligaments, tendons, joint capsule and annulus fibrosis fibres insert into bone. In addition, there is also an increase in the amount of normal cancellous and cortical bone, as well as generalised hyperostosis and a tendency to form post-operative heterotopic new bone [1].

DISH is a systemic condition and not just the result of local mechanical factors present in each of the involved areas of the skeleton. Since the early descriptions of DISH there have been associations with a variety of metabolic factors. Many of these have subsequently been further studied to better define any associations between a particular metabolic factor and DISH. In this report we review the available literature on a number of the putative metabolic factors that have been studied in patients with DISH. Our aim was to identify associations between such factors and DISH in order to better focus future research in this area.

\section{METHODS}

Papers discussed in this review were identified from the authors' own databases and were supplemented with searches on PubMed and online journals. The following keywords were used in various combinations: "diffuse

*Address correspondence to this author at the Suite H, Monash Medical Centre, 246 Clayton Road, Clayton, Victoria, 3168, Australia; Tel: 613 95942575; Fax: 613 95945588; E-mail: geoff.littlejohn@monash.edu idiopathic skeletal hyperostosis", "ankylosing hyperostosis", "Forestier's disease", "diabetes", "insulin", "obesity", "metabolic", "growth factors", "adipokines", "glucose tolerance" and "chondrocytes". The bibliography of relevant identified papers was scanned and information from abstracts and non-English sources was included as deemed relevant. The derived information is presented in summary form. Differences in patient identification and other methodology varied to the degree that formal systematic review was not valid.

The anatomical, radiological and clinical features of DISH have been described under various names for over 150 years. These studies also use different definitions for the diagnosis of DISH. These range from hyperostosis linking two vertebral bodies, without intervening disc disease and extend to different numbers of vertebrae linked by confluent anterior longitudinal ligament related new bone. The different criteria used are summarised in Table 1. In this review we have included studies using different criteria in order to maximize any associations with putative metabolic factors.

\section{Obesity and DISH}

In the defining paper of Forestier and Rotes-Querol it was noted that six of the nine males described with DISH, then termed ankylosing hyperostosis, were stated to be obese [11]. Other subsequent studies have also noted this association.

A series of paleopathological studies is summarized in Table 2. These studies show that there is a significant difference in the prevalence of DISH between groups with 
Table 1. Criteria definitions for diffuse idiopathic skeletal hyperostosis.

\begin{tabular}{|c|c|c|}
\hline Criteria & Characteristics for "Definite" DISH & Comment \\
\hline Contemporary* & Variations on spinal bony bridges. & No specific criteria stated. \\
\hline Julkunen [3] & $\begin{array}{c}\text { Lateral thoracic spine x-ray showing "two typical hyperostotic } \\
\text { bridges". }\end{array}$ & Radiological criteria for epidemiological purposes. \\
\hline Resnick and Niwayama [5] & $\begin{array}{l}\text { Bridging of four contiguous vertebral bodies, minimal } \\
\text { intervertebral disc disease, no facet joint ankylosis and no } \\
\text { sacro-iliac joint inflammatory changes. }\end{array}$ & $\begin{array}{c}\text { Most widely used criteria, does not include extra-spinal } \\
\text { changes. }\end{array}$ \\
\hline Arlet and Maziéres [6] & $\begin{array}{l}\text { Bridging of three contiguous vertebral bodies located in lower } \\
\text { thoracic region, minimal intervertebral disc disease, no facet } \\
\text { joint ankylosis no intra-articular erosion or ossification of } \\
\text { sacro-iliac joints. }\end{array}$ & $\begin{array}{l}\text { "Possible DISH" allowed with variations of criteria } \\
\text { allowed. }\end{array}$ \\
\hline Rogers and Waldron [8] & $\begin{array}{l}\text { Ossification of anterior longitudinal ligament affecting } 3 \\
\text { vertebrae (with/without) ankylosis, confined to right side of } \\
\text { thoracic spine, evidence of symmetrical extra-spinal DISH, } \\
\text { including patellar tufting, heel spurring, olecranon tufting, } \\
\text { ossification of ligamentum flavum and spurring of tibial } \\
\text { tuberosities. Lack of intervertebral changes not required for } \\
\text { diagnosis. }\end{array}$ & Criteria used in paleopathological health assessments. \\
\hline Maat et al. [9] & $\begin{array}{l}\text { Spinal ligament ossifications of four or more contiguous } \\
\text { vertebral levels and/or extensive peripheral enthesopathies }\end{array}$ & Criteria used in paleopathological health assessments. \\
\hline
\end{tabular}

different social status, with specific material from monastic and high-status burial sites being more affected by DISH than remains from laymen burials [12]. The proposition is that the higher social status groups were excessively nourished, with probable increased rates of obesity, compared to the poorer laymen [8]. It is noted that these studies vary in their criteria for defining DISH and that different definitions result in different rates of diagnosis in the same populations [12]. Nevertheless, it is the differences between rates of DISH in the higher and lower social status classes that imply an association between DISH and nutritional factors, particularly those relating to obesity.

In one study the prevalence of DISH in skeletons from cemeteries in churches and chapels, serving priests, monks and lay benefactors, was compared to lay cemeteries in adjacent regions serving the general population [8]. By combining data from the Wells Cathedral and the Royal Mint sites, the authors found that skeletons deemed to derive from high social status individuals had a significantly higher prevalence of DISH compared to those deemed to be of lower social status $(\mathrm{P}<0.001)$. The diet of high social status individuals, such as those living in mediaeval monasteries, was high in animal fat and alcohol [8]. A diet rich in animal fat and alcohol and low in vegetables and fruit has been detailed in members of the Medici family found to have DISH [13].

These findings are consistent across many regions and in different countries even when variations of criteria for diagnosis of DISH are used.

More contemporary clinical data on associations between DISH and obesity are presented in Table 3.

Many of these studies are observational and of historical interest, with no appropriate comparator group. Schilling et al. found higher levels of obesity in patients with DISH compared to controls [24]. Additionally, Julkunen et al. found a significant association between DISH and obesity in a large population survey in Finland [3]. DISH patients had a higher weight - height index compared to controls without DISH, particularly in those over the age of sixty.

An age and sex-matched comparative study of patients with DISH and those with spondylosis showed a significantly higher body mass index [BMI] in the DISH 
Table 2. Paleopathological studies associating DISH in adults with obesity.

\begin{tabular}{|c|c|c|c|c|c|c|}
\hline Author [Year] & No. Subjects & Year & Location & DISH Criteria* & $\begin{array}{l}\text { Percent with } \\
\text { DISH }\end{array}$ & Comment \\
\hline $\begin{array}{c}\text { Waldron [1985] } \\
{[14]}\end{array}$ & 35 monks & $\begin{array}{l}12-16^{\text {th }} \\
\text { century }\end{array}$ & $\begin{array}{l}\text { Merton Priory, } \\
\text { Surrey, UK }\end{array}$ & Resnick & $8.6 \%$ & $\begin{array}{l}\text { Monks were presumed to } \\
\text { be well nourished }\end{array}$ \\
\hline $\begin{array}{l}\text { Rogers et al. } \\
\text { [1985] [15] }\end{array}$ & 303 non-specified & Mediaeval & $\begin{array}{l}\text { Various UK sites, } \\
\text { including churches }\end{array}$ & $\begin{array}{l}\text { "large flowing } \\
\text { spinal osteophytes } \\
\text {-typical of } \\
\text { Forestier's } \\
\text { disease" }\end{array}$ & $2.3 \%$ & $\begin{array}{c}\text { Probable mixed social } \\
\text { status population - } \\
\text { "control” group (includes } 2 \\
\text { high SS clergy with DISH) }\end{array}$ \\
\hline $\begin{array}{c}\text { Bruintjes [1987] } \\
{[16]}\end{array}$ & 1 high SS male & $10^{\text {th }}$ century & $\begin{array}{c}\text { Saint Servaas } \\
\text { Basilica Maastricht } \\
\text { The Netherlands }\end{array}$ & Not known & $100 \%$ & \\
\hline Mays [1991] [17] & $\begin{array}{l}\text { Unclear number } \\
\text { monastic skeletons } \\
51 \text { lay skeletons }\end{array}$ & Mediaeval & $\begin{array}{l}\text { Blackfriars Priory } \\
\text { Ipswich, UK }\end{array}$ & $\begin{array}{l}21 \text { had "DISH", } \\
10 \text { met Rogers and } \\
\text { Waldron criteria } \\
\text { none had DISH }\end{array}$ & $\begin{array}{l}13.4 \% \text { crude } \\
\text { estimate }\end{array}$ & $\begin{array}{l}\text { Skeletons examined from } \\
\text { different grave sites } \\
\text { showed high prevalence of } \\
\text { DISH in high SS } \\
\text { individuals }\end{array}$ \\
\hline $\begin{array}{c}\text { Costa and Weber } \\
{[1995][18]}\end{array}$ & 1 male of high SS & Renaissance & $\begin{array}{l}\text { Basilica of San } \\
\text { Lorenzo Florence } \\
\text { Italy }\end{array}$ & $\begin{array}{c}\text { Not stated - } \\
\text { typical description }\end{array}$ & $100 \%$ & $\begin{array}{c}\text { Another member of Medici } \\
\text { family, obesity } \\
\text { documented in writings } \\
\text { and evident in portraits }\end{array}$ \\
\hline $\begin{array}{l}\text { Maat et al. [1995 } \\
\text { and 1998] [9] [19] }\end{array}$ & $\begin{array}{l}76 \text { and } 316 \text { Friary } \\
\text { skeletons }\end{array}$ & Mediaeval & $\begin{array}{l}\text { Franciscan Priory } \\
\text { Dordrecht } \\
\text { The Netherlands }\end{array}$ & $\begin{array}{l}\text { Rogers and } \\
\text { Waldron }\end{array}$ & $\begin{array}{c}14.5 \%-19 \% \\
\text { crude estimate }\end{array}$ & $\begin{array}{l}\text { High prevalence of DISH } \\
\text { in high SS individuals }\end{array}$ \\
\hline $\begin{array}{c}\text { Janssen and Maat } \\
{[1999][20]}\end{array}$ & 27 Canons & Mediaeval & $\begin{array}{c}\text { Saint Servaas } \\
\text { Basilica Maastricht } \\
\text { The Netherlands }\end{array}$ & $\begin{array}{l}\text { Rogers and } \\
\text { Waldron }\end{array}$ & $100 \%$ & $\begin{array}{l}\text { High prevalence of DISH } \\
\text { in high SS individuals }\end{array}$ \\
\hline Vidal [2000] [21] & 99 non-specified & Mediaeval & Lorraine France & Crubézy & $2.8-3.7 \%$ & $\begin{array}{c}\text { Likely mixed SS } \\
\text { population, indicating a } \\
\text { "control" population }\end{array}$ \\
\hline $\begin{array}{c}\text { Rogers and } \\
\text { Waldron [2001] } \\
{[8]}\end{array}$ & $\begin{array}{c}192 \text { low } \\
\text { SS laymen } \\
80 \text { high SS males }\end{array}$ & Mediaeval & $\begin{array}{l}\text { Wells Cathedral and } \\
\text { Royal Mint } \\
\text { London, UK }\end{array}$ & $\begin{array}{l}\text { Rogers and } \\
\text { Waldron }\end{array}$ & $\begin{array}{c}\text { Low } \mathrm{SS}=3.1 \% \\
\quad \text { High SS } \\
=13.7 \% \\
\mathrm{P}<0.001\end{array}$ & $\begin{array}{l}\text { High prevalence of DISH } \\
\text { in high SS individuals - } \\
\text { "comparative study" }\end{array}$ \\
\hline $\begin{array}{l}\text { Verlaan et al. } \\
\text { [2007] [22] }\end{array}$ & $\begin{array}{l}51 \text { priests, monks, } \\
\text { high status citizens }\end{array}$ & Mediaeval & $\begin{array}{l}\text { Church of Our Lady } \\
\text { Maastricht } \\
\text { The Netherlands }\end{array}$ & $\begin{array}{l}\text { Rogers and } \\
\text { Waldron }\end{array}$ & $\begin{array}{c}40.4 \% \\
10 \text { male, } 5 \\
\text { female, } 2 \text { non- } \\
\text { determinant }\end{array}$ & $\begin{array}{l}\text { High prevalence of DISH } \\
\text { in high SS individuals }\end{array}$ \\
\hline $\begin{array}{l}\text { Giuffra et al. } \\
\text { [2010] [23] }\end{array}$ & 2 males of high SS & Renaissance & $\begin{array}{l}\text { Basilica of San } \\
\text { Lorenzo Florence } \\
\text { Italy }\end{array}$ & $\begin{array}{l}\text { Rogers and } \\
\text { Waldron }\end{array}$ & $100 \%$ & $\begin{array}{l}\text { Members of Medici } \\
\text { family, obesity } \\
\text { documented in writings } \\
\text { and evident in portraits }\end{array}$ \\
\hline
\end{tabular}

*See Table 2 for DISH criteria, NA = not applicable, $\mathrm{SS}=$ social status.

group and as well a higher weight at the age of 25 years in the DISH group (all $\mathrm{p}<0.001$ ) [25].

Mader et al. found significantly higher waist circumference, a marker of obesity and metabolic syndrome [26], in both men and women with DISH [27]. The BMI was statistically higher in both the men and women with DISH compared to the controls and the percentage of DISH patients with BMI above 30, indicating obesity, was also significantly higher.

In a review of patients with psoriatic arthritis [PsA] from the one cohort [28], 78 patients were identified with DISH using the spinal criteria of Utsinger [7]. These patients were compared to 234 PsA patients without DISH from the same cohort. There was a significant increase in BMI in the PsA patients with DISH compared to those with PsA without DISH. Obesity rates were higher in the PsA patients without DISH [mean \pm standard deviation $=50 \pm 33.8$ versus the PsA plus DISH group $[31 \pm 70.5]$. The very high variance in the data makes interpretation of the association of DISH and obesity in this population unclear, although the BMI was significantly elevated.

\section{Diabetes and DISH}

Overlapping and subsequent studies have focussed on the association between DISH and altered glucose tolerance and adult onset Type 2 diabetes mellitus. These studies have 
Table 3. Selected contemporary observations and studies associating DISH with obesity.

\begin{tabular}{|c|c|c|c|c|c|}
\hline Author [Year] & No. Subjects & DISH Criteria* & Obesity Criteria\# & Percentage Obese & Comment \\
\hline $\begin{array}{c}\text { Forestier et al. [1950] } \\
\text { [11] }\end{array}$ & $9 \mathrm{M}$ & Not stated & Not stated & $66 \%$ & $\begin{array}{l}\text { Important clinical } \\
\text { observation } \\
\text { No controls }\end{array}$ \\
\hline $\begin{array}{l}\text { Boulet et al. }[1954] \\
\text { [29] }\end{array}$ & $8 \mathrm{M} / 4 \mathrm{~F}$ & "Forestier" & Not stated & $17 \%$ & No controls \\
\hline $\begin{array}{c}\text { Schoen et al. [1969] } \\
\text { [30] }\end{array}$ & $\begin{array}{l}507 \text { patients, }>30 \mathrm{yrs} \\
\text { with abnormal GT }\end{array}$ & $\begin{array}{l}\text { NS - lateral Xray } \\
\text { thoracic spine }\end{array}$ & NS & "Increased" & $\begin{array}{c}\text { Compared to } 347 \\
\text { patients, }>50 \text { yrs with } \\
\text { normal GT }\end{array}$ \\
\hline $\begin{array}{c}\text { Beardwell [1969] } \\
{[31]}\end{array}$ & $4 \mathrm{M} / 4 \mathrm{~F}$ & "Forestier" & Not stated & "Majority" & Familial study \\
\hline $\begin{array}{l}\text { Harris et al. [1974] } \\
\text { [4] }\end{array}$ & $17 \mathrm{M} / 17 \mathrm{~F}$ & Harris & Not stated & $88 \%$ & No controls \\
\hline $\begin{array}{l}\text { Utsinger et al. [1976] } \\
\text { [32] }\end{array}$ & $25 \mathrm{M} / 5 \mathrm{~F}$ & Resnick & Not stated & $30 \%$ & No controls \\
\hline Resnick [1978] [33] & $21 \mathrm{M}$ & Resnick & Not stated & $22 \%$ & No controls \\
\hline $\begin{array}{c}\text { Boachie-Adjei et al. } \\
\text { [1987] [34] }\end{array}$ & $\begin{array}{l}21 \text { of } 75 \text { autopsy } \\
\text { spines }\end{array}$ & "Forestier" & Average weight & $\begin{aligned} \text { DISH }= & 85 \mathrm{~kg}, \text { non-DISH } \\
= & 65 \mathrm{~kg}\end{aligned}$ & $\begin{array}{c}\text { Obesity strongly } \\
\text { associated with DISH }\end{array}$ \\
\hline $\begin{array}{c}\text { Troillet and Gerster } \\
\text { [1993] [35] }\end{array}$ & $\begin{array}{l}17 \mathrm{M} / 8 \mathrm{~F} \text {, matched } \\
\text { for age, sex, BMI }\end{array}$ & Resnick & BMI & Mean $\mathrm{BMI}=29.5$ & All obese \\
\hline $\begin{array}{l}\text { Coaccioli et al. } \\
\text { [2000] [38] }\end{array}$ & $\begin{array}{c}\text { Obese subjects- [1] } 32 \\
\text { without T2DM, [2] } 30 \\
\text { with T2DM } \\
\text { Control - } 30 \text { subjects }\end{array}$ & Utsinger & $\begin{array}{l}\mathrm{BMI}>30 \\
\mathrm{BMI}<30\end{array}$ & $\begin{array}{c}\text { [1] } 37.5 \% \text { DISH } \\
\text { [2] } 40 \% \text { DISH } \\
2.5 \% \text { DISH }\end{array}$ & $\begin{array}{l}\text { High prevalence DISH in } \\
\text { obese subjects }\end{array}$ \\
\hline $\begin{array}{c}\text { Kiss et al. }[2002] \\
{[25]}\end{array}$ & $\begin{array}{c}69 \mathrm{M} / 62 \mathrm{~F} \text { with } \\
\text { DISH; } 69 \mathrm{M} / 62 \mathrm{~F} \text { with } \\
\text { spondylosis }\end{array}$ & Resnick & BMI & $\begin{array}{c}\text { DISH BMI } 27.8, \text { controls } \\
26.0,[p<0.001]\end{array}$ & $\begin{array}{l}\text { Obesity strongly } \\
\text { associated with DISH }\end{array}$ \\
\hline $\begin{array}{c}\text { Miyazama and } \\
\text { Akiyama [2006] [39] }\end{array}$ & $\begin{array}{c}\text { DISH } 35 \mathrm{M} / 10 \mathrm{~F} \\
\text { Control [spondylosis] } \\
70 \mathrm{M} / 20 \mathrm{~F}\end{array}$ & Resnick & Weight & $\begin{array}{c}\text { DISH mean }=62.3 \mathrm{~kg}, \\
\text { Controls mean }=58.33 \mathrm{~kg} \\
{[\mathrm{p}<0.01]}\end{array}$ & $\begin{array}{l}\text { Obesity strongly } \\
\text { associated with DISH }\end{array}$ \\
\hline $\begin{array}{c}\text { Mader et al. [2009] } \\
\text { [27] }\end{array}$ & $\begin{array}{l}13 \mathrm{M} / 34 \mathrm{~F} \text { DISH; } 48 \\
\text { age-sex matched } \\
\text { controls }\end{array}$ & Resnick & $\begin{array}{c}\text { WC } \\
\mathrm{BMI}>30\end{array}$ & $\begin{array}{l}\text { WC significantly elevated } \\
\text { in DISH, BMI > 30 in } 39 \% \\
\text { DISH versus } 26 \% \text { controls }\end{array}$ & $\begin{array}{l}\text { Obesity strongly } \\
\text { associated with DISH }\end{array}$ \\
\hline $\begin{array}{l}\text { Zincarelli et al. } \\
\text { [2012] [40] }\end{array}$ & $\begin{array}{c}\text { DISH } 105 \mathrm{M} / 27 \mathrm{~F} \\
\text { Non-DISH } 231 \mathrm{M} / 73 \\
\mathrm{~F}\end{array}$ & Resnick & $\mathrm{BMI}>30$ & $\begin{array}{c}35.6 \% \text { DISH obese } \\
\text { compared with } 23 \% \text { non- } \\
\text { DISH } \\
{[\mathrm{p}<0.009]}\end{array}$ & $\begin{array}{c}\text { Obesity strongly } \\
\text { associated with DISH-all } \\
\text { had cardiovascular } \\
\text { disease }\end{array}$ \\
\hline $\begin{array}{l}\text { Haddad et al. [2013] } \\
\text { [28] }\end{array}$ & $\begin{array}{c}57 \mathrm{M} / 21 \mathrm{~F} \text { with DISH } \\
\text { and PsA; } 171 \mathrm{M} / 62 \mathrm{~F} \\
\text { control patients with } \\
\text { PsA only }\end{array}$ & $\begin{array}{l}\text { Modified Utsinger } \\
\text { [thoracic spine } \\
\text { only, no extra } \\
\text { spinal assessment } \\
\text { included] }\end{array}$ & $\begin{array}{c}\text { BMI } \\
\text { Obesity definition } \\
\text { not stated }\end{array}$ & $\begin{array}{c}\text { DISH BMI }=32.9 \%, \text { control } \\
\text { BMI }=28.7 \%, p<0.0001 \\
\text { DISH obesity }=31 \%, \text { control } \\
\text { obesity }=50 \% .[\mathrm{p}<0.0001]\end{array}$ & $\begin{array}{l}\text { Higher BMI strongly } \\
\text { associated with DISH, } \\
\text { large variance in obesity } \\
\text { groups }\end{array}$ \\
\hline
\end{tabular}

$\mathrm{M}=$ males, $\mathrm{F}=$ females, \# Weight-height ratio= weight in kilograms/height in centimetres-100, WC $=$ waist circumference, $\mathrm{BMI}=\mathrm{Body}$ Mass Index, $\mathrm{GT}=$ glucose tolerance, PsA =psoriatic arthritis, * "Forestier" indicates that diagnosis based on typical features of Forestier et al. description [11], ** marker state =weight at time of first marriage. 
looked at various aspects of glucose intolerance defined in different ways. The studies used contemporaneous criteria for the diagnosis of diabetes and/or criteria based on different thresholds for glucose intolerance, following different glucose challenges.

The studies seeking association between DISH and glucose intolerance and/or diabetes have addressed the issue in two ways. Firstly, studies have looked for abnormalities of glucose intolerance in patients defined as having DISH. These are summarized in Table 4.

In a Finnish study Julkunen [3] found a significant difference between the rates of hyperglycaemia in patients with and without DISH $[p<0.05]$. Hyperglycaemia, was defined as $>250 \mathrm{mg} / 100 \mathrm{ml}$ one hour after an oral glucose tolerance test or the presence of established diabetes. Analyses of intercorrelations between glucose tolerance and obesity in this series suggested that decreased glucose tolerance and obesity contributed at least in part to DISH, independently of each other.

Mader found higher fasting glucose levels in DISH patients compared to controls but many in each group were diabetic and medication was not taken into account. Overall these studies are very suggestive of an increased rate of Type 2 diabetes and/or impaired glucose tolerance in patients with diagnosed DISH, although there is marked inconsistency in diagnosis of DISH, selection of controls and definitions used to define diabetes and impaired glucose tolerance.

Another series of studies have sought to assess the rates of DISH in patients with abnormal glucose tolerance or diabetes. These studies also vary significantly with respect to diagnostic criteria and study design and are summarized in Table 5.

Although the quality of these studies varies, there is a general theme indicating that there is an excess prevalence of DISH in patients with diabetes or abnormal glucose tolerance compared to those with normal glucose tolerance. There is an increased prevalence of DISH in diabetic patients recruited from hospital clinics, likely reflecting bias due to comorbidity factors [57]. However, when non-diabetics, aged 60 - 69 years, were compared to diabetics of the same age the prevalence of DISH increased from $4 \%$ to $21 \%$ $[\mathrm{p}<0.001]$ [58].

Additionally, glucose intolerance and obesity seem to act as independent risk factors in their association with DISH [3]. There has been no relationship found between the degree of hyperglycaemia and the severity of the bony change in DISH [48]. Importantly no patient with juvenile onset, i.e., Type 1 [primary insulin deficient] diabetes has been recorded as having DISH.

\section{Growth Hormone and Related Hormones and DISH}

It has been proposed that growth hormone or related hormones may be involved in the new bone growth, and also the increased rates of diabetes, that characterize DISH. Table 6 summarizes selected studies of growth hormone and related peptides in patients with DISH. Growth hormone measured in one study, both after an overnight fast and after a glucose challenge, showed no difference between DISH patients and weight-matched controls [61]. In contrast, in a study that involved DISH subjects that were significantly heavier than the controls the basal growth hormone was also significantly higher [62]. IGF-1 levels were not different to controls. In this study basal insulin was also significantly elevated. Overall, however there is no conclusive data to indicate elevation of growth hormone or Insulin-like growth factor in patients with DISH.

\section{Insulin and Related Hormones and DISH}

Insulin is elevated in Type 2 diabetes mellitus and is a bone growth promoting peptide [69]. Various studies seeking associations of these hormones with DISH are summarized in Table 7.

Insulin, measured both after an overnight fast and after a glucose challenge, showed significant elevation in DISH patients compared to weight and BMI-matched controls $[p<0.001]$ [61]. The change in insulin was noted despite no significant change in blood glucose levels, either at base-line or after glucose stimulation. Insulin levels, measured 2 hours after glucose challenge showed highly significant correlation to BMI in the DISH group. Some studies support this finding [68], while others (as outlined in Table 7) do not.

The fact that insulin levels correlate with being overweight $[55,60,68,70]$ is a potential confounder in these studies.

\section{Adipokines}

The increased rates of obesity, particularly abdominal fat, in patients with DISH might imply a role for various adipokines in the pathogenesis of this disorder. Many of these fat-derived cytokine-like hormones have significant effects on bone metabolism [71].

Leptin is encoded in the obese gene, secreted by adipose tissues and involved in maintenance of weight. Leptin has effects on bone in mice promoting osteoblast numbers and activity through peripheral pathways [72]. In humans leptin levels associate with increase cortical but not cancellous bone [73]. Hereditary obese rats [Zucker fatty (fa/fa) rats] have an aberration of the leptin receptor gene and develop ossification of spinal ligaments [OSL], a condition with similarities to DISH that targets the posterior longitudinal spinal ligament [74]. Japanese female patients with OSL, but not males have elevated leptin, which correlates with elevated insulin levels [74]. There is a positive correlation with extent and severity of ligamentous ossification in OSL [75]. The leptin receptor is expressed in human spinal ligaments, although in vitro studies did not show increased collagen synthesis after exposure to leptin [74]. Both leptin and its receptor are also expressed in the annulus, increasing with advanced age [76]. Leptin is found in high levels in osteophytes of patients with osteoarthritis [77]. Leptin has not been specifically studied in DISH but the studies in the related ossifying disorder of OSL are shown in Table 8. Leptin levels were significantly elevated in females with OSL in this study. 
Table 4. Selected studies of impaired glucose tolerance [IGT], including diabetes mellitus, in patients with DISH.

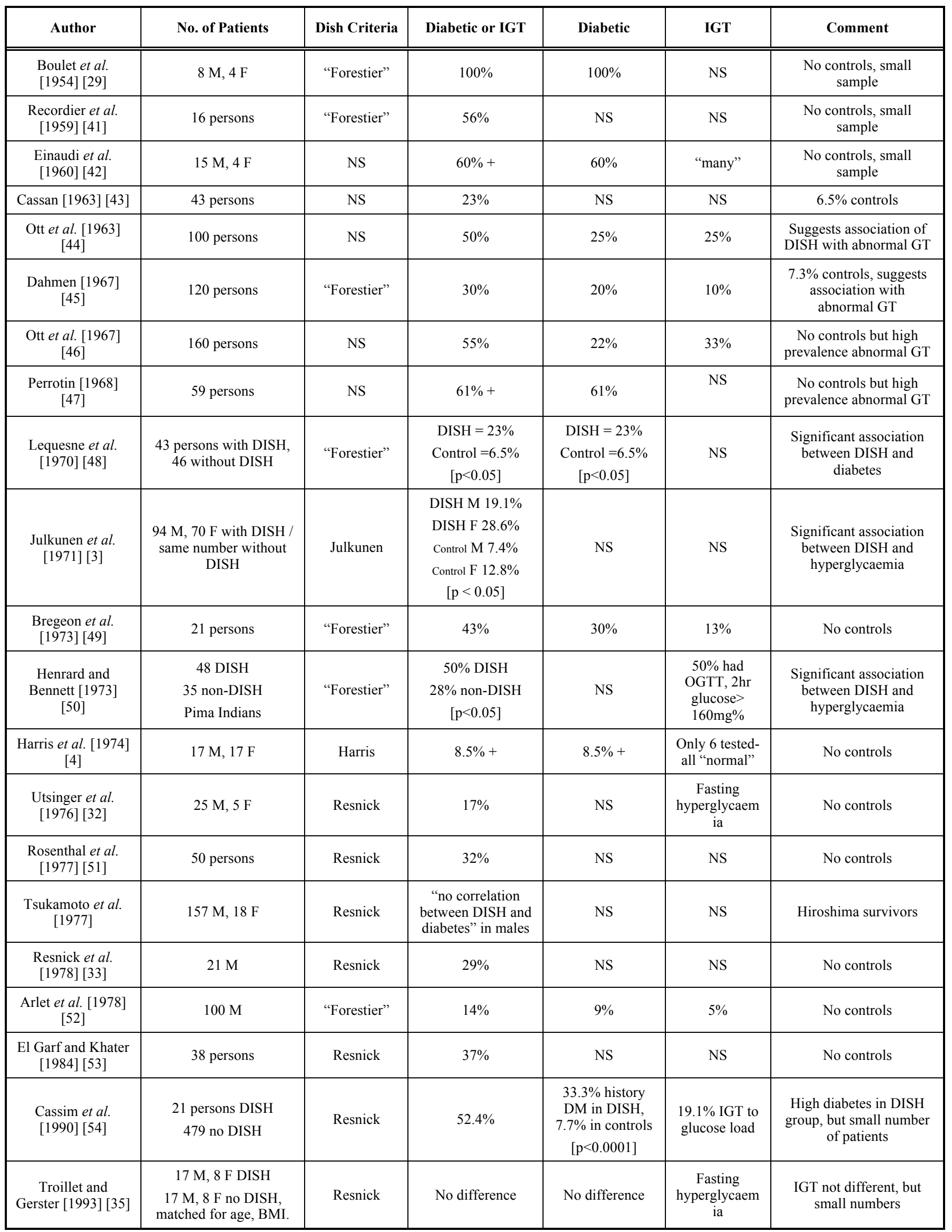




\begin{tabular}{|c|c|c|c|c|c|c|}
\hline Author & No. of Patients & Dish Criteria & Diabetic or IGT & Diabetic & IGT & Comment \\
\hline $\begin{array}{l}\text { Daragon et } \\
\text { al. [1995] } \\
\text { [36] }\end{array}$ & $\begin{array}{c}50 \text { persons -DISH }>60 \mathrm{yrs} \\
50 \text { controls - matched sex, age, } \\
\text { weight, height }\end{array}$ & Resnick & No difference & No difference & $\begin{array}{l}\text { No difference in } \\
\text { glucose } \\
\text { tolerance }\end{array}$ & $\begin{array}{c}\text { No association DISH } \\
\text { and Dbs / } \\
\text { hyperglycaemia. }\end{array}$ \\
\hline $\begin{array}{l}\text { Vezyroglou } \\
\text { et al. } \\
\text { [1996] [55] }\end{array}$ & $\begin{array}{l}100 \text { DISH } \\
100 \text { controls, matched age, sex, } \\
\text { BMI, excess body weight }\end{array}$ & Resnick & No difference & $\begin{array}{l}22 \% \text { in DISH, } \\
3 \% \text { in Controls } \\
{[p<0.0001]}\end{array}$ & & $\begin{array}{c}\text { Increased dyslipidemia } \\
\text { /hyperuricemia } \\
\text { and DM in DISH } \\
{[\mathrm{p}<0.0001]}\end{array}$ \\
\hline $\begin{array}{l}\text { Kiss et al. } \\
{[2002][25]}\end{array}$ & $\begin{array}{l}69 \mathrm{M} \text { / } 62 \mathrm{~F} \text {-DISH; } 69 \mathrm{M} / 62 \mathrm{~F} \\
\text { men /women - spondylosis }\end{array}$ & Resnick & $\begin{array}{c}\text { DISH }=19.8 \% \\
\text { Control }=9.1 \% \\
\quad[p<0.05]\end{array}$ & $\begin{array}{c}\text { DISH }=19.8 \% \\
\text { Control }=9.1 \% \\
\quad[p<0.05]\end{array}$ & NS & $\begin{array}{c}\text { Significant association } \\
\text { between DISH and } \\
\text { diabetes }\end{array}$ \\
\hline $\begin{array}{l}\text { Mader et al. } \\
{[2009][27]}\end{array}$ & $\begin{array}{c}13 \mathrm{M} / 34 \mathrm{~F} \text { DISH; } 48 \text { age-sex } \\
\text { matched controls }\end{array}$ & Resnick & NS & $\begin{array}{c}\text { DISH }=49 \% \\
\text { Control }=33 \% \\
\text { NS }\end{array}$ & $\begin{array}{c}\text { DISH }=40 \% \\
\text { Control }=10 \% \\
\text { Fasting glucose } \\
>110 \mathrm{mg} / \mathrm{dL} \\
{[\mathrm{p}<0.05]}\end{array}$ & $\begin{array}{l}\text { Significant association } \\
\text { between DISH and } \\
\text { hyperglycaemia }\end{array}$ \\
\hline $\begin{array}{l}\text { Eckertova } \\
\quad \text { et al. } \\
\text { [2009] [56] }\end{array}$ & $\begin{array}{c}20 \mathrm{M}, 9 \mathrm{~F}-\mathrm{DISH}, 8 \mathrm{M}, 9 \mathrm{~F}- \\
\text { non-DISH, matched for age, } \\
\text { BMI. }\end{array}$ & Resnick & $\begin{array}{c}\text { DISH }=41.4 \% \\
\text { Control }=7.8 \% \\
\quad[p<0.05]\end{array}$ & NS & $\begin{array}{c}\text { DISH }=41.4 \% \\
\text { Control }=7.8 \% \\
{[p<0.05]}\end{array}$ & $\begin{array}{l}\text { Significant association } \\
\text { between DISH and } \\
\text { hyperglycaemia }\end{array}$ \\
\hline $\begin{array}{l}\text { Zincarelli } \\
\quad \text { et al. } \\
\text { [2012] [40] }\end{array}$ & $\begin{array}{c}\text { DISH } 105 \mathrm{M} / 27 \mathrm{~F} \\
\text { Non-DISH } 231 \mathrm{M} / 73 \mathrm{~F}\end{array}$ & Resnick & $\begin{array}{l}\text { No difference in } \\
\text { rates of T2DM or } \\
\text { fasting blood } \\
\text { glucose }>100 \mathrm{mg} / \mathrm{dl}\end{array}$ & & & $\begin{array}{l}\text { All patients had severe } \\
\text { cardiac disease -no } \\
\text { healthy controls }\end{array}$ \\
\hline
\end{tabular}

$\mathrm{M}=$ males, $\mathrm{F}=$ females, GT = glucose tolerance, IGT = Impaired glucose tolerance, T1DM = Type 1 diabetes mellitus, T2DM = Type 2 diabetes mellitus, NS = not stated, Dbs $=$ diabetes, "Forestier" indicates that diagnosis based on typical features of Forestier et al. description [11].

Table 5. Selected estimates of the prevalence of DISH in patients with abnormal glucose tolerance, including type 2 diabetes mellitus.

\begin{tabular}{|c|c|c|c|c|c|}
\hline Author & No. of Patients & Criteria for Abnormal GT & Dish & Dish Criteria & Comment \\
\hline $\begin{array}{l}\text { Boulet et al. } \\
{[1954][29]}\end{array}$ & 265 persons & All diabetics & $7 \%$ & "Forestier" & No controls \\
\hline $\begin{array}{l}\text { Ott } \text { et al. }[1963] \\
{[44]}\end{array}$ & $\begin{array}{l}82 \text { persons, "mainly } \\
\text { men" }\end{array}$ & NS & $50 \%$ & "Forestier" & "Usually old, benign diabetes" \\
\hline $\begin{array}{l}\text { Hajkova et al. } \\
\text { [1965] [57] }\end{array}$ & $83 \mathrm{~F}, 18 \mathrm{M}$ & NS & $\begin{array}{l}41 \% \mathrm{~F} \\
33 \% \mathrm{M}\end{array}$ & NS & $\begin{array}{l}\text { No controls; age of patient \& duration of } \\
\text { diabetes increase likelihood of DISH }\end{array}$ \\
\hline $\begin{array}{l}\text { Julkunen et al. } \\
\text { [1966] [58] }\end{array}$ & 510 persons & Abnormal fasting BSL & $13 \%$ & Julkunen & Overall prevalence \\
\hline $\begin{array}{l}\text { Julkunen et al. } \\
\text { [1966] [58] }\end{array}$ & 122 persons age $60-69$ & Abnormal fasting BSL & $21 \%$ & Julkunen & $\begin{array}{l}\text { Control group 4\% DISH in } 148 \text { non } \\
\text { diabetics }\end{array}$ \\
\hline $\begin{array}{l}\text { Julkunen et al. } \\
\text { [1968] [59] }\end{array}$ & $\begin{array}{c}83 \mathrm{Db} \mathrm{M} \\
1175 \text { non-Db M }\end{array}$ & $\begin{array}{l}\text { Existing Db or } 2 \text { hour GTT } \\
\text { abnormal }\end{array}$ & $\begin{array}{l}4.8 \% \\
1.6 \%\end{array}$ & Julkunen & $\begin{array}{l}\text { Not significantly different, younger } \\
\text { policemen }\end{array}$ \\
\hline $\begin{array}{l}\text { Schoen et al. } \\
\text { [1969] [30] }\end{array}$ & $\begin{array}{l}507 \text { persons } \\
\text { age }>30 \text { yrs }\end{array}$ & "Overt or latent diabetes" & $25 \%$ & $\begin{array}{l}\text { NS-lateral Xray } \\
\text { thoracic spine }\end{array}$ & $\begin{array}{c}\text { Control group of } 347 \text { non-diabetics, age }> \\
50 \text { yrs }-2.6 \% \text { DISH }\end{array}$ \\
\hline $\begin{array}{c}\text { Ott et al. [1967] } \\
{[46]}\end{array}$ & 105 persons & NS & $44 \%$ & $\begin{array}{l}\text { NS- lateral } \\
\text { CXR }\end{array}$ & No controls \\
\hline Lequesne (1970) & 52 & NS & $29 \%$ & "Forestier" & $13 \%$ in 46 "controls" \\
\hline $\begin{array}{l}\text { Coaccioli et al. } \\
\text { [2000] [38] }\end{array}$ & $\begin{array}{c}170 \text { "consecutive } \\
\text { subjects" - } 130 \\
\text { patients and } 40 \text { normal } \\
\text { subjects }\end{array}$ & $\begin{array}{c}30 \text { T1DM } \\
30 \text { obese T2DM } \\
20 \text { non-obese T2DM } \\
18 \text { IGT } \\
32 \text { obese }[\mathrm{BMI}>30] \\
40 \text { normal subjects }\end{array}$ & $\begin{array}{c}26.6 \% \\
40.0 \% \\
30.0 \% \\
22.2 \% \\
37.5 \% \\
2.5 \%\end{array}$ & Utsinger & $\begin{array}{l}\text { Obese persons and obese diabetics had } \\
\text { highest percentage of DISH. Statistics not } \\
\text { presented, but DISH said to be statistically } \\
\text { increased in these groups. }\end{array}$ \\
\hline $\begin{array}{l}\text { Sencan et al. } \\
\text { [2005] [60] }\end{array}$ & $\begin{array}{l}133 \text { T2 DM outpatients } \\
133 \text { age, sex, weight - } \\
\text { matched, outpatient } \\
\text { controls }\end{array}$ & All Type 2 diabetics & $\begin{array}{c}12.0 \% \text { in } \\
\text { T2DM, } \\
6.8 \% \text { in } \\
\text { Controls } \\
\text { [NS - } \\
\mathrm{p}>0.05]\end{array}$ & Resnick & $\begin{array}{l}\text { Mean weight } 67.7 \text { and } 65.4 \mathrm{kgs} \text {, } \\
\text { respectively }\end{array}$ \\
\hline
\end{tabular}

$\mathrm{M}=$ males, $\mathrm{F}=$ females, NS = not stated, BSL = blood sugar level, DB = diabetic, GTT = glucose tolerance test, CXR = chest X-Ray, "Forestier" indicates that diagnosis based on typical features of Forestier et al. description [11], T2DM = Type 2 diabetes mellitus, kgs = kilograms. 
Table 6. Selected studies of growth hormone and related peptides in DISH.

\begin{tabular}{|c|c|c|c|c|c|}
\hline Author & Patients & Dish Criteria & Methods & Result & Comment \\
\hline $\begin{array}{c}\text { Bregeon et al. [1973] } \\
\text { [49] }\end{array}$ & $10 \mathrm{M}$ & "Forestier" & $\begin{array}{c}\text { Basal and post-glucose } \\
\text { GH }\end{array}$ & GH-Normal levels & Small sample \\
\hline Harris et al. [1974] [4] & 5 younger persons & Harris & NS & GH-Normal levels & Small sample \\
\hline $\begin{array}{c}\text { Resnick et al. [1978] } \\
\text { [33] }\end{array}$ & 6 persons & Resnick & NS & GH -normal levels & Small sample. \\
\hline $\begin{array}{l}\text { Littlejohn and Smythe } \\
\text { [1981] [61, 63] }\end{array}$ & $\begin{array}{c}11 \mathrm{M} \text { DISH } \\
8 \mathrm{M} \text {, age/ weight - } \\
\text { matched no DISH }\end{array}$ & Resnick & $\begin{array}{l}\text { Fasting basal and post- } \\
\text { glucose GH, IGF-1 }\end{array}$ & $\begin{array}{l}\text { GH- no difference } \\
\text { IGF-1 -no difference }\end{array}$ & $\begin{array}{l}\text { Small sample, } \\
\text { controlled for BMI. }\end{array}$ \\
\hline $\begin{array}{l}\text { Altomonte et al. } \\
\text { [1992] [64] }\end{array}$ & $\begin{array}{c}6 \mathrm{M} \text {, non-obese DISH, } \\
10 \mathrm{M} \text {, weight-matched } \\
\text { no DISH }\end{array}$ & Resnick & $\begin{array}{c}\text { Fasting basal and post } \\
\text { insulin tolerance test } \\
\text { [ITT] GH }\end{array}$ & $\begin{array}{c}\text { Basal GH not elevated, } \\
\text { significant GH } \\
\text { elevation post-ITT } \\
\text { compared to control } \\
{[p<0.05]}\end{array}$ & $\begin{array}{l}\text { Only study to show } \\
\text { post stimulation } \\
\text { elevation of GH }\end{array}$ \\
\hline $\begin{array}{c}\text { Denko et al. }[1994] \\
{[62]}\end{array}$ & $\begin{array}{c}14 \text { white M DISH, } \\
22 \mathrm{M} \text { no DISH } \\
8 \text { white F / } 8 \text { black F } \\
\text { DISH, } \\
22 \text { white F/ } 10 \text { black F } \\
\text { no DISH }\end{array}$ & Resnick & $\begin{array}{l}\text { Fasting morning GH, } \\
\text { IGF-1 }\end{array}$ & $\begin{array}{c}\text { GH- elevated } \\
\text { IGF-1-no difference in } \\
\text { males/ black females, } \\
\text { elevated in white } \\
\text { females }\end{array}$ & $\begin{array}{l}\text { Study confounded by } \\
\text { significant differences } \\
\text { in weight, with DISH } \\
\text { groups being heavier. }\end{array}$ \\
\hline $\begin{array}{c}\text { Denko et al. }[1996] \\
{[65]}\end{array}$ & $\begin{array}{c}8 \mathrm{M} \text { DISH } \\
12 \mathrm{M} \mathrm{OA} \\
22 \mathrm{M} \text { no DISH }\end{array}$ & Resnick & $\begin{array}{l}\text { Fasting morning GH, } \\
\text { IGF-1 }\end{array}$ & $\begin{array}{c}\text { Serum IGF-1 - same } \\
\text { as controls, synovial } \\
\text { IGF-1 same as OA. } \\
\text { Serum GH- higher } \\
\text { [and same] in DISH } \\
\text { and OA than controls, } \\
\text { synovial GH same as } \\
\text { OA group. }\end{array}$ & $\begin{array}{l}\text { All DISH patients had } \\
\text { knee effusions, no } \\
\text { matching for weight }\end{array}$ \\
\hline $\begin{array}{c}\text { Denko et al. }[2002] \\
{[66]}\end{array}$ & $\begin{array}{c}15 \mathrm{M} \text { DISH } \\
15 \mathrm{M} \text { controls }\end{array}$ & NS & $\begin{array}{l}\text { Fasting morning GH, } \\
\text { IGF-1 }\end{array}$ & $\begin{array}{l}\text { GH but not IGF-1 } \\
\text { lower in asymptomatic } \\
\text { DISH patients, but NS }\end{array}$ & $\begin{array}{l}\text { Poorly controlled } \\
\text { study }\end{array}$ \\
\hline $\begin{array}{c}\text { Denko et al. }[2003] \\
{[67]}\end{array}$ & $\begin{array}{c}19 \mathrm{M} \text { DISH } \\
34 \mathrm{M} \text { no DISH, not } \\
\text { controlled for weight }\end{array}$ & Resnick & $\begin{array}{l}\text { Fasting morning intra- } \\
\text { erythrocyte GH }\end{array}$ & $\begin{array}{l}\text { Intra-erythrocyte GH } \\
\text { same in DISH and } \\
\text { controls }\end{array}$ & \\
\hline $\begin{array}{c}\text { Sencan et al. }[2005] \\
{[60]}\end{array}$ & $\begin{array}{c}133 \mathrm{~T} 2 \mathrm{DM} \\
\text { outpatients } \\
133 \text { age, sex, weight - } \\
\text { matched, outpatient } \\
\text { controls }\end{array}$ & Resnick & Fasting IGF-1 & No difference & \\
\hline $\begin{array}{c}\text { Denko and Malemud } \\
{[2006][68]}\end{array}$ & $\begin{array}{l}11 \text { DISH with BMI } \\
23-28 \\
10 \text { DISH with BMI } \\
>28\end{array}$ & Resnick & $\begin{array}{l}\text { Fasting morning serum } \\
\text { GH, IGF-1 }\end{array}$ & $\begin{array}{l}\text { GH and IGF-1 no } \\
\text { different between BMI } \\
\text { groups }\end{array}$ & $\begin{array}{l}\text { "Additional" data from } \\
25 \text { DISH patients } \\
\text { showed no correlation } \\
\text { between BMI and GH } \\
\text { or IGF-1. }\end{array}$ \\
\hline $\begin{array}{c}\text { Eckertova et al. [2009] } \\
{[56]}\end{array}$ & $\begin{array}{l}\text { 20M, 9F -DISH } \\
\text { 8M, 5F- no DISH, } \\
\text { matched for age, }\end{array}$ & Resnick & $\begin{array}{l}\text { Fasting and post- } \\
\text { OGTT serum GH, } \\
\text { IGF-1, IGF-BP3 }\end{array}$ & $\begin{array}{c}\text { No difference between } \\
\text { groups }\end{array}$ & \\
\hline
\end{tabular}

$\mathrm{M}=$ males, $\mathrm{F}=$ females, $\mathrm{NS}=$ not stated, $\mathrm{BMI}=$ body mass index, $\mathrm{GH}=$ Growth Hormone, IGF- $1=$ Insulin-like growth factor $-1, \mathrm{OA}=$ osteoarthritis, OGTT $=$ oral glucose tolerance test, IGF-BP3 = insulin-like binding protein 3 , ITT $=$ insulin tolerance test.

In 37 patients with DISH the serum levels of the osteoblast inhibitor Dickkopf-related protein-1 [DKK-1] were significantly lower compared to 22 healthy, agematched controls. Lower levels associated with more spinal hyperostosis independent of age, sex, bone-turnover markers or bone mineral density [78]. However, another study did not find an association between DKK-1 and DISH [79] making this observation difficult to interpret.

\section{BONE REGULATORY PROTEINS}

\section{Co-Morbid Metabolic Factors}

Patients with DISH have significant associations with gout, hyperuricemia and dyslipidaemia, likely through the shared association with obesity [27, 55, 80-84]. There is no evidence that these factors in their own right cause the new bone formation characteristic of DISH 
Table 7. Selected studies of Insulin and related hormones in DISH.

\begin{tabular}{|c|c|c|c|c|c|}
\hline Author & Patients & Criteria & Methods & Result & Comment \\
\hline $\begin{array}{c}\text { Littlejohn and Smythe } \\
\text { [1981] [61] }\end{array}$ & $\begin{array}{c}11 \text { males DISH } \\
8 \text { age, weight-matched } \\
\text { non-DISH males }\end{array}$ & Resnick & $\begin{array}{l}\text { Fasting and post- } \\
\text { glucose insulin }\end{array}$ & $\begin{array}{l}\text { Insulin significantly } \\
\text { elevated in basal and } \\
\text { stimulated state. }\end{array}$ & $\begin{array}{l}\text { Small sample, } \\
\text { controlled for BMI. }\end{array}$ \\
\hline $\begin{array}{c}\text { Altomonte et al. } \\
\text { [1992] [64] }\end{array}$ & $\begin{array}{c}6 \mathrm{M} \text {, non-obese DISH, } \\
10 \mathrm{M} \text {, weight-matched } \\
\text { no DISH }\end{array}$ & "Resnick" & $\begin{array}{l}\text { Fasting and post- } \\
\text { glucose insulin, C- } \\
\text { peptide }\end{array}$ & $\begin{array}{c}\text { No significant } \\
\text { difference to controls }\end{array}$ & \\
\hline $\begin{array}{c}\text { Troillet and Gerster } \\
\text { [1993] [35] }\end{array}$ & $\begin{array}{l}\text { 17M, 8F DISH } \\
\text { 17M, 8F matched for } \\
\text { age, sex, BMI. }\end{array}$ & Resnick & $\begin{array}{l}\text { Fasting glucose, } \\
\text { insulin }\end{array}$ & $\begin{array}{c}\text { No significant } \\
\text { difference to controls }\end{array}$ & \\
\hline $\begin{array}{c}\text { Denko et al. }[1994] \\
\text { [62] }\end{array}$ & $\begin{array}{l}14 \text { white males } \\
22 \text { controls } \\
8 \text { black females } \\
10 \text { controls }\end{array}$ & Resnick & Fasting morning serum & $\begin{array}{l}\text { Insulin - significantly } \\
\text { elevated }\end{array}$ & $\begin{array}{l}\text { Study confounded by } \\
\text { significant differences } \\
\text { in weight, with DISH } \\
\text { groups being heavier. }\end{array}$ \\
\hline $\begin{array}{c}\text { Denko and Malemud } \\
{[2006] \text { [68] }}\end{array}$ & $\begin{array}{c}11 \text { DISH with BMI } \\
23-28 \\
10 \text { DISH with BMI } \\
>28\end{array}$ & Resnick & $\begin{array}{l}\text { Fasting morning } \\
\text { insulin }\end{array}$ & $\begin{array}{c}\text { Insulin elevated } \\
\text { significantly in DISH } \\
\text { with BMI> } 28\end{array}$ & $\begin{array}{l}\text { "Additional" data from } \\
25 \text { DISH patients } \\
\text { showed strong } \\
\text { correlation between } \\
\text { BMI and insulin } \\
\text { levels. }\end{array}$ \\
\hline $\begin{array}{c}\text { Sencan et al. }[2005] \\
{[60]}\end{array}$ & $\begin{array}{c}133 \mathrm{~T} 2 \mathrm{DM} \\
\text { outpatients } \\
133 \text { age, sex, weight - } \\
\text { matched, outpatient } \\
\text { controls }\end{array}$ & Resnick & Fasting insulin & No difference & $\begin{array}{c}\text { Positive correlation } \\
\text { between age and } \\
\text { insulin levels in DISH } \\
\text { patients without } \\
\text { T2DM }\end{array}$ \\
\hline Mader et al. [2009] & $\begin{array}{l}\text { 13/34 male/females } \\
\text { DISH; } 48 \text { age-sex } \\
\text { matched controls }\end{array}$ & Resnick & Fasting insulin & No difference & $\begin{array}{l}\text { BMI in both groups } \\
\quad>30\end{array}$ \\
\hline $\begin{array}{c}\text { Eckertova et al. [2009] } \\
{[56]}\end{array}$ & $\begin{array}{c}\text { 20M, 9F DISH } \\
8 \mathrm{M}, 5 \mathrm{~F} \text { no DISH }\end{array}$ & Resnick & $\begin{array}{l}\text { Fasting and post- } \\
\text { OGTT, serum insulin, } \\
\text { C-peptide }\end{array}$ & No difference & $\begin{array}{c}\text { Decreased } \\
\text { insulinogenic index } \\
\text { and insulin/C-peptide } \\
\text { ratio in DISH }\end{array}$ \\
\hline
\end{tabular}

$\mathrm{M}=$ males, $\mathrm{F}=$ females, $\mathrm{NS}=$ not stated, $\mathrm{BMI}=$ body mass index, $\mathrm{OGTT}=$ oral glucose tolerance test.

Table 8. Selected studies of adipokines in DISH-related disorders.

\begin{tabular}{|c|c|c|c|c|c|}
\hline Author & Patients & Criteria & Methods & Result & Comment \\
\hline $\begin{array}{c}\text { Shirakura et al. [2000] } \\
{[74]}\end{array}$ & $\begin{array}{c}\text { 32M/17F patients with } \\
\text { OSL; 37M/32F age } \\
\text { and BMI-matched } \\
\text { controls }\end{array}$ & $\begin{array}{l}\text { Patients with OSL } \\
\text { identified -no criteria }\end{array}$ & $\begin{array}{l}\text { Serum leptin } \\
\text { and insulin }\end{array}$ & $\begin{array}{c}\text { Leptin and insulin } \\
\text { significantly elevated } \\
\text { in female but not male } \\
\text { OSL patients }\end{array}$ & $\begin{array}{c}\text { The elevated leptin in females } \\
\text { with OSL may link to insulin. } \\
\text { The significance of this } \\
\text { observation is unclear. No } \\
\text { positive findings in males. }\end{array}$ \\
\hline $\begin{array}{c}\text { Ikeda et al. }[2011] \\
{[75]}\end{array}$ & $\begin{array}{c}\text { 68M/57F patients with } \\
\text { OSL; } 35 \mathrm{M} / 27 \mathrm{~F} \text { age } \\
\text { and BMI-matched } \\
\text { controls }\end{array}$ & $\begin{array}{l}\text { Patients with OSL } \\
\text { identified -no criteria }\end{array}$ & $\begin{array}{l}\text { Serum leptin, } \\
\text { insulin }\end{array}$ & $\begin{array}{l}\text { Leptin and insulin } \\
\text { significantly elevated } \\
\text { in females corrected } \\
\text { for BMI, but not male } \\
\text { OSL patients }\end{array}$ & $\begin{array}{l}\text { Elevated leptin and insulin } \\
\text { correlated with extent of spinal } \\
\text { ossification in females. } \\
\text { Inconclusive associations with } \\
\text { bone turnover. No positive } \\
\text { findings in males. }\end{array}$ \\
\hline
\end{tabular}

$\mathrm{OSL}=$ ossification of spinal ligaments, $\mathrm{BMI}=$ body mass index.

\section{Vitamin A}

Vitamin A -related products can cause hyperostosis in animals and man $[85,86]$. Vitamin $\mathrm{A}$ has been shown to be elevated in patients with DISH [87] but it remains unclear as to the exact role of Vitamin A in DISH.

\section{Animal Models}

DISH has been described in numerous animal species but there are no well-designed animal experiments to demonstrate the causal relationship between metabolic factors and DISH $[88,89]$. 


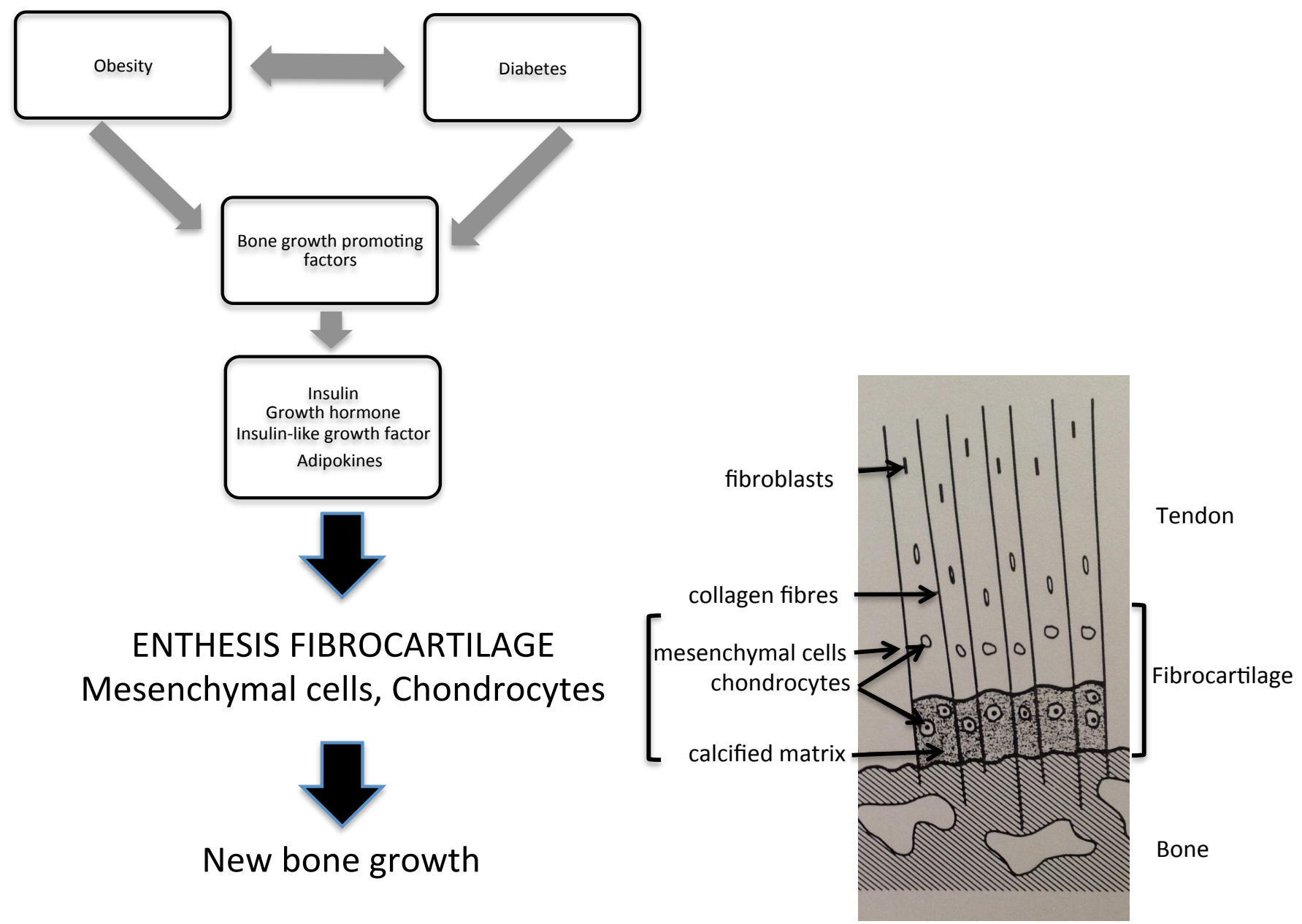

Fig. (1). Growth factors present in patients with DISH, such as growth hormone, insulin or insulin-like growth factor, target the chondrocytes and mesenchymal cells in the uncalcified portion of the enthesis. Proliferation of these cell types results in new bone formation. The components of the enthesis are detailed in the diagram to the right. Molecular mechanisms within the entheseal cells have been recently summarized [92].

\section{Metabolic Factors and Targets in DISH}

The metabolic factors present in patients with DISH, such as insulin, likely interact with key candidate cellular targets linking to new bone formation. These include chondrocytes and periosteal mesenchymal cells within the enthesis $[90,91]$ (See Fig. 1). These cells have been shown to proliferate under the influence of transforming growth factor- $\beta 1$, insulin and bone morphogenic protein (BMP2) to form fibroblasts, myoblasts and osteoblasts [91]. Metabolic factors, such as insulin, growth hormone and insulin-like growth factor 1 , all have the ability to promote bone formation through stimulation of proliferation of osteoblasts, chondrocytes and fibroblasts $[82,84]$. The exact mechanisms that contribute to the new bone growth, particularly in entheseal regions, in patients with DISH are unknown. However, relevant important signalling pathways are likely to include the Wnt $-\beta$-catenin pathway, nuclear factor $\kappa \mathrm{B}$, BMP2, prostaglandin I2 and endothelin1 [92].

\section{FUTURE STUDIES}

There is a need for further studies to better define the important background metabolic factors that promote the new bone formation that characterizes DISH. These need to include a group of interacting factors, including genetic, epigenetic, metabolic and bone-related signalling pathways. Study of younger patients with early DISH may better identify important metabolic factors but this approach is limited by current diagnostic criteria that identify wellestablished DISH, with high rates of confounding comorbidities [93]. It is important for future studies to incorporate direct examination of the cellular elements of the key target organ of DISH, the enthesis.

\section{SUMMARY}

This review examines the available literature on metabolic factors in patients with DISH. The identified literature was not considered robust enough to perform a structured systematic review due to inconsistencies with study methodologies. These include different criteria for diagnosis of DISH, and different definitions for diabetes, and impaired glucose tolerance. Metabolic studies varied in the protocols used, with different time frames and stimulation protocols. Controls were often lacking or poorly matched for metabolic factors. We have commented on these issues in the summary tables. 
Nevertheless we aimed to make this review a contemporary summary on the topic to act as a reference standard for future studies.

Despite the above comments this review of metabolic factors in DISH does allow for certain conclusions. There is a general theme that metabolic factors are of great importance in DISH. Obesity, particularly abdominal obesity, is strongly linked to DISH. Further exploration of the role adipokines in patients with DISH is required. Type 2 diabetes is increased in DISH, independent of obesity. The link between obesity, type 2 diabetes and insulin elevation is strong. Of all the potential growth factors examined in patients with DISH, insulin is likely to have a key role in the pathophysiology of DISH.

Finally, it is clear that more studies are required on this important aspect of DISH, a condition that is increasing in frequency and significance.

\section{CONFLICT OF INTEREST}

The authors confirm that this article content has no conflict of interest.

\section{ACKNOWLEDGEMENTS}

Declared none.

\section{REFERENCES}

[1] Littlejohn GO. Diffuse idiopathic skeletal hyperostosis. In: Hochberg M, Silman A, Weinblatt M, Weisman M, Eds. Rheumatology. Philadelphia, Mosby Elsevier. 2011; 1801-6.

[2] Bywaters EGL, Doyle FH, Oakley N. Senile hyperostotic ankylosing spondylosis (Forestier and Querol) in diabetes mellitus. Arthritis Rheum 1966; 9: 495.

[3] Julkunen H, Heinonen OP, Pyorala K. Hyperostosis of the spine in an adult population. Its relation to hyperglycaemia and obesity. Ann Rheum Dis 1971; 30: 605-12.

[4] Harris J, Carter AR, Glick EN, Storey GO. Ankylosing hyperostosis. I. Clinical and radiological features. Ann Rheum Dis 1974; 33: 210-5.

[5] Resnick D, Niwayama G. Radiographic and pathologic features of spinal involvement in diffuse idiopathic skeletal hyperostosis (DISH). Radiology 1976; 119: 559-68.

[6] Arlet J, Mazieres B. La maladie hyperostique. Rev Med Interne 1985; 5: 553-64.

[7] Utsinger PD. Diffuse idiopathic skeletal hyperostosis. Clin Rheum Dis $1985 ; 11: 325-51$

[8] Rogers J, Waldron T. DISH and the monastic way of life. Int J Osteoarcheol 2001; 11: 357-65.

[9] Maat GJR, Mastwijk RW, Van der Velde EA. Skeletal distribution of degenerative changes in vertebral osteophytosis, vertebral osteoarthritis and DISH. Int J Osteoarchaeol 1995; 5: 289-98.

[10] Crubezy E, Crubezy-Ibanez E. [Evaluation of diagnostic criteria for hyperostotic diseases on a series of skeletons. Epidemiological implications]. Rev Rhum Ed Fr 1993; 60: 586-90.

[11] Forestier J, Rotes-Querol J. Senile ankylosing hyperostosis of the spine. Ann Rheum Dis 1950; 9: 321-30.

[12] van der Merwe AE, Maat GJ, Watt I. Diffuse idiopathic skeletal hyperostosis: diagnosis in a palaeopathological context. Homo 2012; 63: 202-15.

[13] Fornaciari G. Food and disease at the renaissance courts of naples and florence: a paleonutritional study. Appetite 2008; 51: 10-4.

[14] Waldron T. DISH at Merton Priory: evidence for a "new" occupational disease? Br Med J (Clin Res Ed) 1985; 291: 1762-3.

[15] Rogers J, Watt I, Dieppe P. Palaeopathology of spinal osteophytosis, vertebral ankylosis, ankylosing spondylitis, and vertebral hyperostosis. Ann Rheum Dis 1985; 44: 113-20.
[16] Bruintjes TJD. Diffuse idiopathic skeletal hyperostosis (DISH). A 10th century AD case from St Servaas church at Maastricht. Bone 1987; $1: 23-8$.

[17] Mays S. The Medieval Burials from the Blackfriars Friary, School Street, Ipswich, Suffolk. Ancient Monuments Laboratory Report 16/91. In: English London: Heritage; 1991.

[18] Costa A, Weber G. Le alterazioni morbose del sistema scheletrico in Cosimo dei Mediciil vecchio, in Piero il Gottoso, in Lorenzo il Magnifico, in Giuliano Duca di Nemours. Arch de Vecchi Anat Patol 1995; 23: 1-69.

[19] Maat GJR, Mastwijk RW, Sarfatij H. Een fysisch anthropologisch onderzoek van begravenen bij het Minderbroedersklooster te Dordricht, circa 1275-1572 AD. In: ROB: Amersfoort; 1998.

[20] Janssen HAM, Maat GJR. Canons buried in the 'Stiftskapel' of the Saint Servaas Basilica at Maastricht AD 1070-1521. A paleolopathological study, Barge's Anthropologica No 5. In: Barge's Anthropologica. Leiden, 1999.

[21] Vidal P. A paleoepidemiologic study of diffuse idiopathic skeletal hyperostosis. Joint Bone Spine 2000; 67: 210-4.

[22] Verlaan JJ, Oner FC, Maat GJ. Diffuse idiopathic skeletal hyperostosis in ancient clergymen. Eur Spine J 2007; 16: 1129-35.

[23] Giuffra V, Giusiani S, Fornaciari A, Villari N, Vitiello A, Fornaciari G. Diffuse idiopathic skeletal hyperostosis in the Medici, Grand Dukes of Florence (XVI century). Eur Spine J 2010; 19 Suppl 2: S103-7.

[24] Schilling F, Schacherl M, Camp A, Bopp A. Die beziehungen der spondylosis hyperostotica zur konstitution and $\mathrm{zu}$ stoffwechselstorungen. Med Klin 1965; 60: 165.

[25] Kiss C, Szilagyi M, Paksy A, Poor G. Risk factors for diffuse idiopathic skeletal hyperostosis: a case-control study. Rheumatology (Oxford) 2002; 41: 27-30.

[26] Schneider HJ, Glaesmer H, Klotsche J, Bohler S, Lehnert H, Zeiher AM, Marz W, Pittrow D, Stalla GK, Wittchen HU, Group DS Accuracy of anthropometric indicators of obesity to predict cardiovascular risk. J Clin Endocrinol Metab 2007; 92: 589-94.

[27] Mader R, Novofestovski I, Adawi M, Lavi I. Metabolic syndrome and cardiovascular risk in patients with diffuse idiopathic skeletal hyperostosis. Semin Arthritis Rheum 2009; 38: 361-5.

[28] Haddad A, Thavaneswaran A, Toloza S, Chandran V, Gladman DD. Diffuse Idiopathic Skeletal Hyperostosis in Psoriatic Arthritis. J Rheumatol 2013; 40(8): 1367-73.

[29] Boulet P, Serre H, Mirouze J. Le rachis diabetique. Sem Hop Paris 1954; 30: 2392-410.

[30] Schoen D, Oldershausen FV, Vogt W. Ist die hyperostatische spondylosis deformans eine diabetische osteopathie? Fortschr Rontgenstr 1969; 110: 525-39.

[31] Beardwell A. Familial ankylosing vertebral hyperostosis with tylosis. Ann Rheum Dis 1969; 28: 518-23.

[32] Utsinger PD, Resnick D, Shapiro R. Diffuse skeletal abnormalities in Forestier disease. Arch Intern Med 1976; 136: 763-8.

[33] Resnick D, Shapiro RF, Wiesner KB, Niwayama G, Utsinger PD, Shaul SR. Diffuse idiopathic skeletal hyperostosis (DISH) [ankylosing hyperostosis of Forestier and Rotes-Querol]. Semin Arthritis Rheum 1978; 7: 153-87.

[34] Boachie-Adjei O, Bullough PG. Incidence of ankylosing hyperostosis of the spine (Forestier's disease) at autopsy. Spine (Phila Pa 1976) 1987; 12: 739-43.

[35] Troillet N, Gerster JC. [Forestier disease and metabolism disorders. A prospective controlled study of 25 cases]. Rev Rhum Ed Fr 1993; 60: 274-9.

[36] Daragon A, Mejjad O, Czernichow P, et al. Vertebral hyperostosis and diabetes mellitus: a case-control study. Ann Rheum Dis 1995; 54: 375-8.

[37] Mata S, Fortin PR, Fitzcharles MA, et al. A controlled study of diffuse idiopathic skeletal hyperostosis. Clinical features and functional status. Medicine (Baltimore) 1997; 76: 104-17.

[38] Coaccioli S, Fatati G, Di Cato L, et al. Diffuse idiopathic skeletal hyperostosis in diabetes mellitus, impaired glucose tolerance and obesity. Panminerva Med 2000; 42: 247-51

[39] Miyazawa N, Akiyama I. Diffuse idiopathic skeletal hyperostosis associated with risk factors for stroke: a case-control study. Spine (Phila Pa 1976) 2006; 31: E225-9; discussion E230.

[40] Zincarelli C, Iervolino S, Di Minno MN, et al. Diffuse idiopathic skeletal hyperostosis prevalence in subjects with severe atherosclerotic cardiovascular diseases. Arthritis Care Res 2012; 64: $1765-9$. 
[41] Recordier AM, Jouve G, Allignol J-M. L'hyperostose vertebrale chez les diabetiques. Marseille Med 1959; 96: 711-8.

[42] Einaudi G, Viara M. Ricerche sul metabolismo degli idrati di carbonio nei malata affetti da arthrosi vertebral a carattere iperostosante. Rheumatismo 1960; 12: 163-8.

[43] Cassan P. L'hyperostose vertebrale ankylosante et ses rapports avec le diabete sucre. Etude cliniqueet statistique. Memoire CES, Paris, 1963.

[44] Ott VR, Schennkenbecher H, Iser H. Die spondylose bei diabetes mellitus. Z Rheumaforsch 1963; 22: 278-90.

[45] Dahmen G. Bezeichnungen der spondylosis hyperostotica zur diabetogen stoffwechsellage. In: VIth Congres european de rheumatologie; Lisbon: 1967; pp. 316.

[46] Ott VR, Perkovak N, Regehr I. Hyperostotic spondylosis and ankylosing spondylitis; correlation with disorders of carbohydrate metabolism. In: 6th European Congess of Rheumatology; Lisbon: 1967; pp. 95.

[47] Perrotin C. Contribution a l'etude de 1;hyperostose vertebral ankylosante: ses rapports eventuels avec l'obesite et l'etate diabetique. In: Med. Marseille, 1968.

[48] Lequesne M, Cassan P, Nallet J. Hyperostose vertebrale et diabete sucre. Rev Rhum Mal Osteoartic 1970; 37: 281-6.

[49] Bregeon C, Chevalier J, Bigorgne JC, Renier JC. [Ankylosing vertebral hyperostosis. Etiological investigations and search for a hypersecretion of growth hormone]. Rev Rhum Mal Osteoartic 1973; 40: 319-27.

[50] Henrard JC, Bennett PH. [Epidemiological study of vertebral hyperostosis. Survey in an adult population of American Indians]. Rev Rhum Mal Osteoartic 1973; 40: 581-91.

[51] Rosenthal M, Bahous I, Muller W. Increased frequency of HLA B8 in hyperostotic spondylosis. J Rheumatol Suppl 1977; 3: 94-6.

[52] Arlet J, Jacqueline F, Depeyre M, et al. Le hanche dans l'hyperostose vertebrale ankylosante. Rev Rhum Mal Osteoartic 1978; 45: $17-26$.

[53] el-Garf A, Khater R. Diffuse idiopathic skeletal hyperostosis (DISH). A clinicoradiological study of the disease pattern in Middle Eastern populations. J Rheumatol 1984; 11: 804-7.

[54] Cassim B, Mody GM, Rubin DL. The prevalence of diffuse idiopathic skeletal hyperostosis in African blacks. Br J Rheumatol 1990; 29: 131-2.

[55] Vezyroglou G, Mitropoulos A, Antoniadis C. A metabolic syndrome in diffuse idiopathic skeletal hyperostosis. A controlled study. J Rheumatol 1996; 23: 672-6.

[56] Eckertova M, Krskova K, Penesova A, et al. Impaired insulin secretion and uptake in patients with diffuse idiopathic skeletal hyperostosis. Endocr Regul 2009; 43: 149-55.

[57] Hajkova Z, Streda A, Skrha F. Hyperostotic spondylosis and diabetes mellitus. Ann Rheum Dis 1965; 24: 536-43.

[58] Julkunen H, Karava R, Viljanen V. Hyperostosis of the spine in diabetes mellitus and acromegaly. Diabetologia 1966; 2: 123-6.

[59] Julkunen H, Pyorala K, Lehtovirta E. Hyperostosis of the spine in relation to age and hyperglycemia in men aged 30-69. Ann Med Intern Fenn 1968; 57: 1-7.

[60] Sencan D, Elden H, Nacitarhan V, Sencan M, Kaptanoglu E. The prevalence of diffuse idiopathic skeletal hyperostosis in patients with diabetes mellitus. Rheumatol Int 2005; 25: 518-21.

[61] Littlejohn GO, Smythe HA. Marked hyperinsulinemia after glucose challenge in patients with diffuse idiopathic skeletal hyperostosis. J Rheumatol 1981; 8: 965-8.

[62] Denko CW, Boja B, Moskowitz RW. Growth promoting peptides in osteoarthritis and diffuse idiopathic skeletal hyperostosis-insulin, insulin-like growth factor-I, growth hormone. J Rheumatol 1994; 21: 1725-30.

[63] Littlejohn GO, Herington AC, Smythe HA. Studies into various growth factors in diffuse idiopathic skeletal hyperostosis (DISH) [Forestier's Disease]. In: ILAR Rheumatology Conference. Rev Rhum Mal Osteoartic: Paris, 1981.

[64] Altomonte L, Zoli A, Mirone L, et al. Growth hormone secretion in diffuse idiopathic skeletal hyperostosis. Ann Ital Med Int 1992; 7: 30-3.

[65] Denko CW, Boja B, Moskowitz RW. Growth factors, insulin-like growth factor-1 and growth hormone, in synovial fluid and serum of patients with rheumatic disorders. Osteoarthritis Cartilage 1996; 4: 245-9.

[66] Denko CW, Boja B, Malemud CJ. Growth hormone and insulinlike growth factor-I in symptomatic and asymptomatic patients with diffuse idiopathic skeletal hyperostosis (DISH). Front Biosci 2002; 7: a37-43.

[67] Denko CW, Boja B, Malemud CJ. Intra-erythrocyte deposition of growth hormone in rheumatic diseases. Rheumatol Int 2003; 23: $11-4$

[68] Denko CW, Malemud CJ. Body mass index and blood glucose: correlations with serum insulin, growth hormone, and insulin-like growth factor-1 levels in patients with diffuse idiopathic skeletal hyperostosis (DISH). Rheumatol Int 2006; 26: 292-7.

[69] Akune T, Ogata N, Seichi A, Ohnishi I, Nakamura K, Kawaguchi $\mathrm{H}$. Insulin secretory response is positively associated with the extent of ossification of the posterior longitudinal ligament of the spine. J Bone Joint Surg Am 2001; 83-A: 1537-44.

[70] Silveri F, Brecciaroli D, Argentati F, Cervini C. Serum levels of insulin in overweight patients with osteoarthritis of the knee. J Rheumatol 1994; 21: 1899-902.

[71] Lago F, Dieguez C, Gomez-Reino J, Gualillo O. Adipokines as emerging mediators of immune response and inflammation. Nat Clin Pract Rheumatol 2007; 3: 716-24.

[72] Turner RT, Kalra SP, Wong CP, et al. Peripheral leptin regulates bone formation. J Bone Miner Res 2013; 28: 22-34.

[73] Li H, Jiang LS, Dai LY. Hormones and growth factors in the pathogenesis of spinal ligament ossification. Eur Spine J 2007; 16 : 1075-84.

[74] Shirakura Y, Sugiyama T, Tanaka H, Taguchi T, Kawai S. Hyperleptinemia in female patients with ossification of spinal ligaments. Biochem Biophys Res Commun 2000; 267: 752-5.

[75] Ikeda Y, Nakajima A, Aiba A, et al. Association between serum leptin and bone metabolic markers, and the development of heterotopic ossification of the spinal ligament in female patients with ossification of the posterior longitudinal ligament. Eur Spine J 2011; 20: 1450-8.

[76] Zhao CQ, Liu D, Li H, Jiang LS, Dai LY. Expression of leptin and its functional receptor on disc cells: contribution to cell proliferation. Spine (Phila Pa 1976) 2008; 33: E858-64.

[77] Presle N, Pottie P, Dumond H, et al. Differential distribution of adipokines between serum and synovial fluid in patients with osteoarthritis. Contribution of joint tissues to their articular production. Osteoarthr Cartil 2006; 14: 690-5.

[78] Senolt L, Hulejova H, Krystufkova O, et al. Low circulating Dickkopf-1 and its link with severity of spinal involvement in diffuse idiopathic skeletal hyperostosis. Ann Rheum Dis 2012; 71: 71-4.

[79] Aeberli D, Schett G, Eser P, Seitz M, Villiger PM. Serum Dkk-1 levels of DISH patients are not different from healthy controls. Joint Bone Spine 2011; 78: 422-3.

[80] Littlejohn GO, Hall S. Diffuse idiopathic skeletal hyperostosis and new bone formation in male gouty subjects. A radiologic study. Rheumatol Int 1982; 2: 83-6.

[81] Fornaciari G, Giuffra V, Giusiani S, Fornaciari A, Villari N, Vitiello A. The 'gout' of the Medici, Grand Dukes of Florence: a palaeopathological study. Rheumatology (Oxford) 2009; 48: 375-7.

[82] Sarzi-Puttini P, Atzeni F. New developments in our understanding of DISH (diffuse idiopathic skeletal hyperostosis). Curr Opin Rheumatol 2004; 16: 287-92.

[83] Mader R, Sarzi-Puttini P, Atzeni F, et al. Extraspinal manifestations of diffuse idiopathic skeletal hyperostosis. Rheumatology (Oxford) 2009; 48: 1478-81.

[84] Mader R, Verlaan JJ. Bone: Exploring factors responsible for bone formation in DISH. Nat Rev Rheumatol 2012; 8: 10-2.

[85] Nesher G, Zuckner J. Rheumatologic complications of vitamin A and retinoids. Semin Arthritis Rheum 1995; 24: 291-6.

[86] Ling TC, Parkin G, Islam J, Seukeran DC, Cunliffe WJ. What is the cumulative effect of long-term, low-dose isotretinoin on the development of DISH? Br J Dermatol 2001; 144: 630-2.

[87] Abiteboul M, Arlet J, Sarrabay MA, Mazieres B, Thouvenot JP. [Metabolism of vitamin A in Forestier-Rotes-Querol hyperostosis] Rev Rhum Mal Osteoartic 1986; 53: 143-5.

[88] Lagier R. Spinal hyperostosis in comparative pathology. A useful approach to the concept. Skeletal Radiol 1989; 18: 99-107.

[89] Kranenburg HC, Westerveld LA, Verlaan JJ, et al. The dog as an animal model for DISH? Eur Spine J 2010; 19: 1325-9.

[90] Littlejohn GO. Insulin and new bone formation in diffuse idiopathic skeletal hyperostosis. Clin Rheumatol 1985; 4: 294-300. 
[91] Berthelot JM, Le Goff B, Maugars Y. Pathogenesis of hyperostosis: A key role for mesenchymatous cells? Joint Bone Spine 2013; 80: 592-6.

[92] Mader R, Verlaan JJ, Buskila D. Diffuse idiopathic skeletal hyperostosis: clinical features and pathogenic mechanisms. Nat Rev Rheumatol 2013; 9: 741-50.
[93] Mader R, Buskila D, Verlaan JJ, Atzeni F, Olivieri I, Pappone N, Di Girolamo C, Sarzi-Puttini P. Developing new classification criteria for diffuse idiopathic skeletal hyperostosis: back to square one. Rheumatology (Oxford) 2013; 52: 326-30.

(C) Pillai and Littlejohn; Licensee Bentham Open.

This is an open access article licensed under the terms of the Creative Commons Attribution Non-Commercial License (http://creativecommons.org/licenses/by-nc/

3.0/) which permits unrestricted, non-commercial use, distribution and reproduction in any medium, provided the work is properly cited. 